\title{
Evaluation of Different Blended Fertilizers Types and Rates for Better Production of Wheat in Lemu Woreda
}

\author{
Yehuala Alemneh ${ }^{1, *}$, Zerihun Achiso ${ }^{2}$, Tsadiku Bamud ${ }^{2}$ \\ Southern Agricultural Research Institution, Areka Agricultural Research Center, Wolyita, Ethiopia
}

\section{Email address:}

${ }^{*}$ Corresponding author

\section{To cite this article:}

Yehuala Alemneh, Zerihun Achiso, Tsadiku Bamud. Evaluation of Different Blended Fertilizers Types and Rates for Better Production of Wheat in Lemu Woreda. American Journal of Agriculture and Forestry. Special Issue: Agricultural Extension and Agricultural Advice. Vol. 8, No. 4, 2020, pp. 108-111. doi: 10.11648/j.ajaf.20200804.13

Received: February 29, 2020; Accepted: April 23, 2020; Published: June 28, 2020

\begin{abstract}
Ethiopia is likely to rely on the agricultural sector as a source of income and employment for the foreseeable future requiring optimal and up to date fertilizer recommendation packages for all crops given the fact that increasing small holder farmers' productivity. The field experiment was conducted during 2017/18 cropping season at Hadiya zone lemu woreda testing site of Areka Agricultural Research center, southern Ethiopia to evaluate the effect of blended fertilizer on yield of wheat with the treatments of six replicated three times in RCBD design. The treatments were: control (no fertilizer), NPS $\left(92 \mathrm{~N}, 54 \mathrm{P}_{2} \mathrm{O}_{5}, 10 \mathrm{~S}\right)$, and four rates of NPSB $\left(46 \mathrm{~N}, 54 \mathrm{P}_{2} \mathrm{O}_{5}, 10 \mathrm{~S}, 1.07 \mathrm{~B} ; 69 \mathrm{~N}, 72 \mathrm{P}_{2} \mathrm{O}_{5}\right.$, $13 \mathrm{~S}, 1.4 \mathrm{~B}$, and $\left.92 \mathrm{~N}, 90 \mathrm{P}_{2} \mathrm{O}_{5}, 17 \mathrm{~S}, 1.7 \mathrm{~B}\right)$. The plot size was $4 \mathrm{~m}$ by $4 \mathrm{~m}\left(16 \mathrm{~m}^{2}\right)$ andthespacing between plots and blocks was $50 \mathrm{~cm}$ and $100 \mathrm{~cm}$, respectively. The result of this experiment has substantiated the importance of application of NPSB (combination of B with macronutrients NPS) fertilizers in improving yield of wheat in the study area. Despite the need of verification in multi-locations and soil types for wider use, application of NPSB can be recommended for wheat production in the study area.
\end{abstract}

Keywords: Blended, Wheat, Fertilizer, Cereal Productivity

\section{Introduction}

About one third of the world population consume wheat as staple food [1] and as compared with other cereal crops, it is reach protein and providing more [2].

Wheat (TriticumaestivumL.) is an important food crop in Ethiopia, which accounts for $15.65 \%$ of the total cereal output [3]. However, the national average of wheat is $(2.54 \mathrm{t}$ ha-1) in 2015 [4], this very low compare with world average. Crop productivity minimal is due to depletion of nutrients, and poor management practices [5].

Ethiopia is likely to rely on the agricultural sector as a source of income and employment for the foreseeable future requiring optimal and up to date fertilizer recommendation packages for all crops given the fact that increasing small holder farmers' productivity entails the integration of improved technology and adoption. Nutrient mining due to sub optimal fertilizer use coupled with imbalanced fertilizer uses have favored the emergence of multi nutrient deficiency in Ethiopian soils [6], which in part explain fertilizer factor productivity decline and stagnant crop productivity conditions encountered despite continued use the blanket recommendation. The research result from eastern Uganda also showed that the use of low levels of $\mathrm{N}$ and $\mathrm{P}$ fertilizers on maize and beans was the leading factor for nutrient depletion [7, 8]. Balanced fertilizers containing $\mathrm{N}, \mathrm{P}, \mathrm{K}, \mathrm{S}, \mathrm{B}$ and $\mathrm{Zn}$ in blend form have been recommended to ameliorate site specific nutrient deficiencies and there by increase land, water and labor productivity. The work of Wassie and Shiferaw [8] in southern Ethiopia provides a striking example of how fertilizer use efficiency of potato can be raised when NP fertilizers are combined with $\mathrm{K}$ on a location-specific basis. In this study supplementation of $\mathrm{K}$ increased potato tuber yields by $197 \%$ over the standard N-P recommendation alone. The recent national soil inventory data also revealed S, B and $\mathrm{Zn}$ deficiencies are 
widespread in Ethiopian soils, while some soils are also deficient in $\mathrm{K}, \mathrm{Cu}, \mathrm{Mn}$ and $\mathrm{Fe}$ [9], which all potentially hold back crop productivity. However, fertilizer trials involving multi-nutrient blends that include micronutrients are rare. Very recently, a soil test based fertilizer recommendation and calibration efforts have been made by EIAR and RARIs but only limited to certain location and crop types.

According to EthioSIS fertilizer type recommendation map/atlas, eight types of fertilizer blends are identified for SNNPRS. Similarly four types of fertilizers for Lemuworeda and one types of fertilizer/blends were identified for Bobichokebele. But this needs validation for the fertilizer rates for the identified fertilizer types for specific crops. Therefore, this study was initiated with the objectives of (1) Evaluate the relative influences of NPSB on wheat production and (2) Determine optimum rate NPSB for production of wheat in Lemuworeda.

\section{Materials and Methods}

\subsection{Experimental Details and Treatment Set-ups}

On station experiment was carried out for two years (2016 $\&$ 2017) at sub-station, Lemuworeda, Hadiya zone to evaluate the yield response of wheat to application of different soil fertility map based blended fertilizer types and rates. The treatments were laid out in RCBD replicated three times across farmers. Six treatments: control (no fertilizer), NPS $\left(92 \mathrm{~N}, 54 \mathrm{P}_{2} \mathrm{O}_{5}, 10 \mathrm{~S}\right)$, and four rates of NPSB $(46 \mathrm{~N}, 54$ $\mathrm{P}_{2} \mathrm{O}_{5}, 10 \mathrm{~S}, 1.07 \mathrm{~B} ; 69 \mathrm{~N}, 72 \mathrm{P}_{2} \mathrm{O}_{5}, 13 \mathrm{~S}, 1.4 \mathrm{~B}$, and $92 \mathrm{~N}, 90$ $\mathrm{P}_{2} \mathrm{O}_{5}, 17 \mathrm{~S}, 1.7 \mathrm{~B}$,). The plot size was $4 \mathrm{~m}$ by $4 \mathrm{~m}\left(16 \mathrm{~m}^{2}\right)$ and the spacing between plots and blocks was $50 \mathrm{~cm}$ and $100 \mathrm{~cm}$, respectively. Rate of NPSB blend was determined for production of wheat at Lemu and NPS was included for comparison purpose. NPS and NPSB fertilizers were applied at planting whereas urea fertilizer is top dressed after 45 days of planting the test crop. The improved wheat variety Hidase was drilled in rows of $20 \mathrm{~cm}$ after fertilizers drilled and thinly cover by soil. All field managements were carried as per the recommendation of the area and all field observations were recorded.

\subsection{Soil Sampling and Analysis}

Composite surface $(0-20 \mathrm{~cm}$ depth) soil samples were collected from each experimental site before planting and from each treatment at harvesting using auger for selected physic-chemical analysis. The collected samples were properly labeled, packed and transported to the Soil laboratory and were prepared and analyzed according to the standard procedures. [10].

\subsection{Agronomic Data Collection}

Data were collected from the experiment on growth, yield and yield component related parameters on plot and plant basis. Plant height $(\mathrm{cm})$, spike length $(\mathrm{cm})$, tiller number/plant biomass and grain yields were recorded and subjected to analysis of variance (ANOVA).

\subsection{Data Analysis}

ANOVA was carried out using SAS version 9.2 statistical software programs. Significant difference between and among treatment means were assessed using the least significant difference (LSD) at 0.05 level of probability [11].

\section{Results and Discussion}

Soil Chemical Properties of Experimental Sites

Composite surface $(0-20 \mathrm{~cm}$ depth) soil samples were collected from each experimental site before planting. Some selected soil chemical properties of experimental sites and their summary are presented below table.

Table 1. Initial soil sample result.

\begin{tabular}{lllll}
\hline pH & \%OC & \%TN & P.ppm & kav.ppm \\
\hline 6.05 & 1.3 & 0.11 & 41.1 & 84.5 \\
\hline
\end{tabular}

The $\mathrm{pH}$ of the soil is 6.05 slightly acidic and satisfactory for most crops [12].

Total nitrogen of the study areas was $0.11 \%$ that qualify for adequate as suggested [13].

Available Phosphorus is 41.1 very high according to classification of Olsen 1954 [14].

Table 2. Mean (combined over years) wheat yield and yield components as influenced by different blended fertilizer types and rates in Lemu woreda.

\begin{tabular}{|c|c|c|c|c|c|c|}
\hline Trt No. & Treatments & Plant height (cm) & Spike length (cm) & Tiller no & Biomass (tone/ha) & Grain yield (kg/ha) \\
\hline $\mathrm{T} 1$ & Control & $79.4 b$ & $7.6 \mathrm{~b}$ & $2.7 \mathrm{~b}$ & $5.75 \mathrm{~b}$ & $3093.7 b$ \\
\hline $\mathrm{T} 2$ & $\mathrm{NPS}=92,54,10$ & $87.6 \mathrm{a}$ & $8.1 \mathrm{ab}$ & $3.6 \mathrm{ab}$ & $7.60 \mathrm{a}$ & $3687.4 \mathrm{a}$ \\
\hline $\mathrm{T} 3$ & $\mathrm{NPSB}=46,54,10,1.07$ & $89.6 \mathrm{a}$ & $8.2 \mathrm{ab}$ & $3.7 \mathrm{a}$ & $7.79 \mathrm{a}$ & $3635.3 \mathrm{a}$ \\
\hline $\mathrm{T} 4$ & $\mathrm{NPSB}=69,72,13,1.4$ & $86.03 \mathrm{ab}$ & $8.4 \mathrm{a}$ & $4.14 \mathrm{a}$ & $8.06 \mathrm{a}$ & $3676 a$ \\
\hline T5 & $\mathrm{NPSB}=92,90,17,1.7$ & $85.9 \mathrm{ab}$ & $8.5 \mathrm{a}$ & $3.3 \mathrm{ab}$ & $7.58 \mathrm{a}$ & $3614.4 \mathrm{ab}$ \\
\hline \multirow[t]{3}{*}{ T6 } & $\mathrm{NPSB}=92,36,10,1.07$ & $86.9 \mathrm{a}$ & $8.1 \mathrm{ab}$ & $3.5 \mathrm{ab}$ & $7.24 \mathrm{a}$ & $3343.6 \mathrm{ab}$ \\
\hline & $\mathrm{CV}$ & 6.47 & 7.35 & 22.5 & 15.31 & 12.84 \\
\hline & LSD & 6.59 & 0.71 & 0.94 & 1.33 & 534.04 \\
\hline
\end{tabular}

Two years mean yield and yield components results of wheat are presented in table 2. Significant differences were observed among treatments over control $(\mathrm{P}<0.05)$, however, there were no significant difference between fertilizer types (NPS single rate and NPSB -four rates) and among different rates of NPSB for all tested parameters. 
Application of NPS @ $92 \mathrm{~N}, 54 \mathrm{P}_{2} \mathrm{O}_{5}$, and $10 \mathrm{~S}$ equally affected grain yield of wheat at Lemu with application of NPSB@ 46, 54, 10, and 1.07 and other rates of NPSB which needs further investigation. From view point of soil fertility map fertilizers type rate determination of NPSB, NPSB @ 46, 54, 10, 1.07 gave comparable yield with its higher rates.

Partial budget analysis results indicated that application of
NPSB @ the rate of $46 \mathrm{~N}, 54 \mathrm{P}_{2} \mathrm{O}_{5}, 10 \mathrm{~S}$ and $1.07 \mathrm{~B}$ gave highest net benefit and \%MRR (Table 3). From our current field experiment and partial budget analysis result it could be concluded that application NPSB @ the rate of $46 \mathrm{~N}, 54 \mathrm{P}_{2} \mathrm{O}_{5}$, $10 \mathrm{~S}$ and $1.07 \mathrm{~B}$ could be recommended for wheat production and economically feasible in Lemu woreda and similar agro ecology and soil types.

Table 3. Partial budget analysis of fertilizers on wheat at Lemu.

\begin{tabular}{|c|c|c|c|c|c|c|c|c|c|c|}
\hline No. & Treatment & $\begin{array}{l}\text { grain } \\
\text { yield }\end{array}$ & $\begin{array}{l}10 \% \\
\text { Adjusted } \\
\text { yield }\end{array}$ & $\begin{array}{l}\text { gross } \\
\text { benefit } \\
\text { (ETB) }\end{array}$ & $\begin{array}{l}\text { fertilizer } \\
\text { cost }\end{array}$ & $\begin{array}{l}\text { fert. } \\
\text { Appln } \\
\text { Cost }\end{array}$ & TVC & $\begin{array}{l}\text { Net } \\
\text { benefit } \\
\text { birr/ha }\end{array}$ & $\begin{array}{l}\text { MRR } \\
\text { ratio }\end{array}$ & $\%$ MRR \\
\hline $\mathrm{T} 1$ & Control & 3093.7 & 2784.3 & 27843.3 & 0 & 0 & 0 & 27843.3 & & $\mathrm{D}$ \\
\hline T6 & $\mathrm{NPSB}=92,36,10,1.07$ & 3343.6 & 3009.2 & 30092.4 & 2127 & 500 & 2626.5 & 25578.7 & -0.862 & $\mathrm{D}$ \\
\hline $\mathrm{T} 3$ & $\mathrm{NPSB}=46,54,10,1.07$ & 3635.3 & 3271.8 & 32717.7 & 2550 & 400 & 2950 & 29767.7 & 12.95 & $1294.8 \%$ \\
\hline $\mathrm{T} 2$ & $\mathrm{NPS}=92,54,10$ & 3687.4 & 3318.7 & 33186.6 & 3150 & 600 & 3750 & 29436.6 & -0.414 & $\mathrm{D}$ \\
\hline $\mathrm{T} 4$ & $\mathrm{NPSB}=69,72,13,1.4$ & 3676 & 3308.4 & 33084 & 3475 & 500 & 3975 & 29109 & -1.456 & $\mathrm{D}$ \\
\hline T5 & $\mathrm{NPSB}=92,90,17,1.7$ & 3614.4 & 3253.0 & 32529.6 & 3914 & 600 & 4513.7 & 28015.9 & -2.03 & $\mathrm{D}$ \\
\hline
\end{tabular}

\section{Conclusion and Recommendation}

Low and/or unbalanced inorganic fertilizers use was major cause for low production of crops and nutrient mining of the soils. Replenishment of deficient fertilizer nutrients based on soil test is a good strategy to improve crop production productivity in sustainable way. From the near past (last five to eight years) identification of deficient nutrient elements of soil of the country by ATA (agricultural transformation agency) and formulation of different fertilizer types for the country helped the farmers to shift from urea and DAP use to more balanced/blended fertilizers (macro and micro nutrients) use. Some recent reports indicated that nutrients like $\mathrm{K}, \mathrm{S}, \mathrm{Ca}, \mathrm{Mg}$ and micronutrients particularly $\mathrm{Cu}, \mathrm{Mn}, \mathrm{B}$, Mo and $\mathrm{Zn}$ are becoming depleted and deficiency symptoms are being observed on major crops in different areas of the country. The result of this experiment also has substantiated the importance of application of NPSB (combination of B with macronutrients NPS) fertilizers in improving yield of wheat in the study area. Therefore, despite the need of verification in multi-locations and soil types for wider use, application of NPSB at rate of 46, 54, 10, 1.07 respectively can be recommended for wheat production at the study area.

\section{Acknowledgements}

I would like to offer great thanks to southern Agricultural Research Institution for providing funds to the research work. A Special thanks to also goes to Natural Resource management division staffs at Areka Agricultural research centre for the field data collection and laboratory analysis.

\section{References}

[1] Wheat (Triticumaestivum L.) varieties to different levels of N, P and K. Int. J. of Agri. and Bio. 4 (3): 362-364. Hussain MI and SH Shah. (2002). Growth, yield and quality response of three.

[2] Iqtidar H, Muhammad AK and AK Ejaz. (2006). Bread wheat varieties as influenced by different nitrogen levels. J.; Zhejiang Univ. Sci. 7 (1): 70-78.

[3] Central Statistical Authority of Ethiopia (CSA). (2015). Agricultural sample survey 2014/2015. Report on area and production for major crops (Vol. 1). Addis Ababa: National Statistics.

[4] Central Statistical Authority of Ethiopia (CSA). (2016). Agricultural sample survey 2015/2016. Report on area and production for major crops (Vol. 1). Addis Ababa: National Statistics.

[5] Gebreselassie, Y. (2002). Selected chemical and physical characteristics of soils of Adet research center and its testing sites in North-western Ethiopia. Ethiopian Journal of Natural Resources.

[6] Wassie H and Shiferaw B (2011): Response of Irish potato (Solanumtuberosum L.) to the application of potassium at acidic soils of Chencha, Southern Ethiopia. Int. J. Agric. \& Biol. 13: 595-598.

[7] Asgelil D, Taye B, Yesuf A (2007). The status of Micronutrients in Nitisols, Vertisois, Cambisols and Fluvisols in major Maize, Wheat, Teff and Citrus growing areas of Ethiopia. In: Proceedings of Agricultural Research Fund, pp 77-96.

[8] Wortmann, C. S., and C. K. Kai zzi. 1998. Nutrient balances and expected elects of alternative practice $\mathrm{s}$ in farming systems of Uganda. Agric. Ecosyst. E nviron. 71: 115-129. doi: 10.1016/S0167-8809(98)00135-2.

[9] EthioSIS (Ethiopian Soils Information System). 2013. Status of soil resources in Ethiopia and priorities for sustainable management, GSP for eastern and southern Africa Mar 25-27, 2013 Nairobi, Kenya.

[10] SahlemedhinSertsue and TayeBekele, 2000. Procedures for soil and plant analysis. National Soil Research Center, Ethiopian Agricultural Research Organization, Addis Ababa, Ethiopia. $110 \mathrm{p}$.

[11] Gomez, K. A. and Gomez, A. (1984) Statistical Procedure for Agricultural Research-Hand Book. John Wiley \& Sons, New York.

[12] Hach Company (1992) Water Analysis Handbook. 2nd Edition, Hach Company, Loveland, Colorado, USA, 303, 669-3050. 
[13] Bremener, J. M. and C. S. Mulvancy, 1982. Total Nitrogen. In Page, A. L., R. H. Miller and D. R. Keenney. Methods of soil analysis. 2. Chemical and microbiological properties. Agronomy Monograph No. 9 (2nd ed) Madison, Wisconsim, USA: American Soc. Of Agronomy.
[14] Olsen, S. R., Cole, C. V., Watanabe, F. S., \& Dean, L. A. (1954). Estimation of available phosphorus in soils by extraction with sodium bicarbonate. Circular, Vol 939 (p. 19). Washington, DC: US Department of Agriculture. 